\title{
EXPLORING CULTURAL ORIENTATION ON THE ENTREPRENEUR COMPETENCIES IN THE GLOBALIZATION ERA
}

\author{
Mira Rochimi MUTIARA ${ }^{1}$, Ina PRIMIANA ${ }^{2}$, Joeliaty JOELIATY ${ }^{3}$, \\ Martha Fani CAHYANDITO ${ }^{4}$
}

\author{
Faculty of Economics and Business, University of Padjajaran, Bandung, Indonesia \\ E-mails: ${ }^{1}$ myra.mutiara@gmail.com (corresponding author); ${ }^{2}$ ina.primiana@unpad.ac.id; \\ 3joeliaty@unpad.ac.id; ${ }^{4}$ martha.fani@unpad.ac.id
}

Received 9 April 2019; accepted 10 June 2019

\begin{abstract}
The existence of globalization concept absolutely brings consequences for business environment. Based on international literature, cultural orientation was required on business management in the globalization era. Nevertheless, there have been few numbers of cross-cultural entrepreneurship research. Previous research tended to focus on discussing cultural dimensions or using them in entrepreneurship. Therefore, this study proposes a different perspective which is to explore the cultural dimensions for the formation of entrepreneur competencies. Thus, this study aims at suggesting conceptual models and providing empirical evidence concerning national and individual cultural orientation including its role in influencing the formation of Small and Medium Enterprises (SMEs) entrepreneur competencies in facing the globalization era. For this purpose, the survey questionnaire was distributed to 129 SMEs entrepreneurs in the fashion sector in West Java - Indonesia, which was then tested by using VSM 1994 Formula, SPSS method and Partial Least Square (PLS) method. The findings and originality of this study were the novelty of national and its individual cultural values for Indonesia. Moreover, this study discovered that Cultural Orientation significantly influenced the form of entrepreneur competencies. Thus, the role of cultural orientation cannot be ignored in enhancing the ability of SMEs entrepreneurs to face the globalization era.
\end{abstract}

Keywords: Small and Medium Enterprises (SMEs), cultural orientation, national culture, individual cultural, entrepreneur competencies, globalization.

JEL Classification: L26, M16, 015.

\section{Introduction}

One of globalization impacts is that all business entities in the world, including SMEs entrepreneurs, could not avoid cross-country business interactions and the opening of economic market. By this fact, to be able to compete, they must develop entrepreneurial skills and capabilities that are relevant to the demands of times, namely the business capabilities in cross cultures and in the technology era (Temtime 2005). According to Hofstede (1980), cultural dimension offers several advantages in entrepreneurial behavior in understanding different cultural contexts and having a major impact on the economic health of a country by encouraging certain values that help or hinder economic growth. However, based on the results of interviews in this study, Cultural Orientation in Indonesia has been unknown and has never been used in the management of SMEs. Therefore, the Consideration of Cultural Orientation on Entrepreneur Competencies Models in the globalization era is an effort to accompany the global economy and cross-border business opportunities, which require understanding of entrepreneurs from various countries with different attitudes and adopted values (Steensma et al. 2000). Hence, SMEs fashion entrepreneurs are able to improve their competencies, which are expected to have an impact on Indonesia's competitiveness.

Copyright ( 2019 The Authors. Published by VGTU Press.

This is an Open Access article distributed under the terms of the Creative Commons Attribution License (http://creativecommons.org/licenses/by/4.0/), which permits unrestricted use, distribution, and reproduction in any medium, provided the original author and source are credited.. 
Several studies have been conducted in identifying and analyzing the culture and its impacts to form entrepreneurial competencies. One of them is Hofstede's research conducted to perform a survey of values relating to employment in Indonesia in 1991. At that time, Indonesia was mapped by Hofstede to have a cultural dimension of large power distance (score 78), collectivism (family with score 14), low masculine (score 46), and weak uncertainty avoidance (score 48). This means that the Indonesian people were strongly influenced by power (in this case the state/government) and family, and tended to avoid change. Nowadays, there have been many changes in the Indonesian culture. Johnson and Lenartowicz (1998), Lim (2001), Rujirawanich et al. (2011), and Sajilan and Tehseen (2015) proposed to replicate Hofstede's obsolete data due to rapid economic transformation, which can lead to cultural values changes. Therefore, it is necessary to update the Hofstede's data in Indonesia related to the world of jobs.

Likewise the condition in Malaysia, there is necessity to update the Hofstede's outdated data due to the significant economic growth of Malaysian workforce over the past 30 years (Lim 2001, Sajilan and Tehseen 2015). In line with this, Rujirawanich et al. (2011) stated that Thailand's national culture had changed under global media attack, especially to young people. This changed the way of Thailand culture and influenced organizational dynamics. Based on these references, seeing the facts of change in Indonesia, updating Hofstede's data is also valid to Indonesia. Thus, it appears to know "What is the description of National Culture in Indonesia at this time?".

There is one different study on cultural dimension. Richter et al. (2016) did study on culture as a configuration of various cultural dimensions. This concept was developed from Hofstede's theory, in which country is considered as a medium or to present certain culture where each member of the group (individual) has similar thinking pattern. Richter et al. have different opinion with Hofstede's. They see members of a groups as different individual, even though they are in the same environment, they still have different thinking pattern. The difference can be seen in individual's behaviour. By referring to Richter's standpoint, we agree that in each difference of cultural dimension of certain culturem there are several different archetypes in each cultural dimension. Hence, this study seeks to dig "What cultural archetypes exist in Indonesian society?"

The interesting proposition about using new dimension concept with this archetype is not only to explore cultural differences among countries, but also to explore differences of each individual. This is in accordance with the State of Indonesia having a diversity of cultures (ethnics). More interestingly, this concept is to be applied in the business world. The use of cultural archetypes in individual cultural dimension makes it possible to better gain insight on complex and diverse cultural traits, especially when measuring their impacts on entrepreneurial competencies which are elaborated in the next section of this study.

In addition, several studies identified and analyzed relationships or examined cultural influences to form entrepreneurial competencies. One of them is Ahmad's (2007) study which links the relationship of Cultural Orientation to Entrepreneurship Competence aiming at obtaining behaviors that describe individual competencies. Therefore, identification of entrepreneurial competencies is needed in the current business environment with cultural variations among countries. Likewise, Johnson et al. (2006) examined the formation of cross-cultural competencies in entrepreneurial activities in international business and stated that cross-cultural competencies research is very rare and still lacks adequate conceptualization.

This study was conducted in the Fashion Sector SMEs in West Java, Indonesia. Its consideration is that fashion is the most prominent sector contributing to Indonesia's creative industry (BPS-Bekraf2016). The province in Indonesia that has performed the most creative economy exports is West Java Province. Its export value in 2015 was $33.56 \%$ of Indonesia's total exports. Meanwhile, for exports in fashion sector, West Java dominated almost $50 \%$ with the achievement of $42.52 \%$. In addition, the fashion sector was also the most potential to involve SMEs in the international expansion (BPS-Bekraf 2016). However, based on the result of interviews, it was assessed that there were not many West Java SMEs in fashion sector and had not been able to export. Therefore, based on international literature's references stating that in the globalization era, cultural aspects are needed, the role of cultural orientation is crucial to improve the ability of Indonesian SMEs entrepreneurs in fashion sector for international expansion.

Consequently, this study is expected to identify national and individual cultural values while proposing a conceptual model and proving empirically about the role of cultural orientation that influences the formation of SMEs entrepreneur competencies to face the globalization era. This study is a response to get more recent empiricism that expands Hofstede's literature and adds to the cross-cultural entrepreneurship literature and fills the gap in the lack of cross-cultural competencies research.

\section{Literature review}

\subsection{Cultural orientation}

Cultural Orientation theory has been implemented on several aspects of human's life. The most common used is Hofstede's theory. Although the relationship between culture and entrepreneurship has not been formed in Hofstede's work, the cultural dimension is used to identify key factors of culture related to the entrepreneurial activity 
(Casero et al. 2012). It is strengthened by the opinion of Abbey (2002) who examined cross-cultural differences on motivation for entrepreneurship; Ahmad (2007) who identified additional categories of entrepreneurial competencies for different cultural contexts, while Richter Hauff et al. (2016) performed the development of Hofstede's concept which views members of a group as different individuals with different mindsets, despite having the same environment.

This study adopted the construct of Cultural Orientation from Hofstede (1980) and Richter et al. (2016) that is in line with the aim of this study. Thus, the definition of the construct of Cultural Orientation in this study is a form of collective or national thinking that distinguishes a cultural group between countries and the thinking of each individual contributing to the formation of entrepreneurial competencies. Meanwhile, the dimensions of the construct of Cultural Orientation in this study is adopted from Hofstede, namely Power Distance, Individualism vs. Collectivism (IDV vs. COLL), Masculinity vs Femininity (MAS vs. FEM), Uncertainty Avoidance (UAI), and Long Term Orientation vs. Short Term Orientation (STO vs LTO).

\subsection{Cross-cultural competencies}

Cross-Cultural is a crucial matter to answer the phenomenon of globalization. It was previously predicted by Johnson et al. (2006) stating that realizing the global values means dealing locally with various cultures and businesses. Therefore, the ability such as cross-cultural is the answer to face the new globalization era which will help managers or entrepreneurs to manage risks in global economic that will give the impact to the growth of productivity and the improvement of competitive ability (Hasan 2007, Muzychenko 2008). Groves and Feyerherm's (2011) research offering empirical evidence on the importance of cultural intelligence as the competencies that facilitate the leaders' performance outcome in diversity and global working environment). Besides that, cross-cultural competencies are also recognized as the important factor in international business cooperation (Cao 2012). This is confirmed by the opinion of Caligiuri and Tarique (2012) discovering that cross-cultural dynamic competencies become effective predictors for global leadership and professional practice for different cultural clients (Lee 2016). Thus, cross-cultural capabilities as competencies are needed for business interaction in the culture.

This study proposes Cross-Cultural Competencies as the ability to think, move, and behave in the form of interaction or communication, the concern for differences, and the ownership of rational or intellectual aspects in a cultural perspective to form entrepreneurial competencies. Thus, cross-cultural competencies of this study consist of three dimensions which are Cross-Cultural
Communication, Multicultural Awareness, and Cultural Cognitive Intelligence.

\subsection{Entrepreneurial competencies}

Bird (1995) states which Entrepreneurial Competencies are linked with the formation, viability, growth of the business, and proved that the entrepreneur's skills will develop someones's business performance, expansion, or growth. Meanwhile, Man et al. (2002) affirm that evolving the competencies of entrepreneurial is more essential is more essential compared to allocating more resources. In their article, after introducing the concept of competitiveness of SMEs, a competence approach was introduced to study the characteristics of entrepreneurship. By developing from the research of Man et al., Ahmad (2007) conducted a study of entrepreneurial competence models in a cross-cultural business perspective environment.

Subsequently, Gerli et al. (2011) analyzed the role of individual competence with a focus on measuring Entrepreneurial Competencies. The results showed that it was very important for entrepreneurs to develop certain competencies. In addition, Neneh and Vanzyl (2012) adopted the theoretical framework on achieving long-term SMEs and empirically tested the validity that entrepreneurs who posses all entrepreneurial competencies will have bigger opportunity to achieve SMEs survival. Based on the creative industry's perspective, Khalid and Bhatti (2015) discussed the role of entrepreneurs in analyzing the impact of international entrepreneurial decision-making styles and the influence of globalization on entrepreneurship and internationalization of SMEs (export expansion/foreign markets). Meanwhile, Bacigalupo et al. (2016) conducted a study of Entrepreneurial Competencies for European Union Entrepreneurs, which defined Entrepreneurial Competencies for all areas of life.

Nevertheless, related to globalization era, it is not only an element of culture, but also the development of technology. Therefore, in the entrepreneurial competencies, a digital competency is included. Although there are a lot of studies on entrepreneurship, unfortunately, the study on technology and entrepreneurship is still relatively few numbers (Ilomäki et al. 2011, Ngoasong 2017, Van Deursen and Van Dijk 2009) especially in developing countries (Ngoasong 2017). Even those associated with the role of cultural orientation are still very rare.

Therefore, this study intends to fill the gap of study on entrepreneurial digital competencies.

This study defines the entrepreneurial competencies construct as an ability possessed in the knowledge of a particular field, the skill of carrying out activities, and consistent behavior with the required values as the SMEs entrepreneurial competencies of fashion creative industry in the Integrated Economic Community (AEC). The dimensions 
of this construct consist of Conceptual Thinking, Learning to learn, People Related which are adapted from Regional Model Competency Standards (RMCS) Model conducted by ILO (2015), Specific as special abilities (unique characteristics) based on the requirements of industry, and Digital adapted from the International Computer Driving License (ICDL) (2018).

\subsection{The relationship between the role of cultural orientation and the formation of cross-cultural competencies, and entrepreneurial competencies on entrepreneur competencies model}

\subsubsection{Cultural orientation to cross-cultural competencies}

Although Johnson et al. (2006) study found that Cultural Orientation had a negative side to international business, we still consider the scarcity and uniqueness of link between Cultural Orientation and Cross-Cultural Competencies. Since, according to Steensma et al. (2000), cultural orientation has an influence on thinking and behavior, it is expected to form cross-cultural capabilities that are very important in the new globalization era. Based on the explanation, it is possible to formulate the following proposed hypothesis:

Hypothesis 1: Cultural Orientation has a significant effect on Cross-Cultural Competencies.

\subsubsection{Cultural orientation to entrepreneurial competencies}

Culture colors the behavior of entrepreneurs in running a business. Essentially, Cultural Orientation has been implemented to support entrepreneurial activities, especially those people who operate across countries (Abbey 2002, Ahmad 2007, Sajilan and Tehseen 2015). Culture will also affect the level of entrepreneurship (Casero et al. 2012, SeonYoo 2015) and ultimately becomes the global competitiveness of the nation (Lee and Peterson 2001). Meanwhile, the study of Hull et al. (2007) stated that in the digital world, millions of people from various cultures and backgrounds are interacted every day, even though several entrepreneurs and industries use digital only as the tool to run their business or entrepreneurship (Ngoasong 2017). Based on the above explanation, the proposed hypothesis is:

Hypothesis 2: Cultural Orientation has significant effect on Entrepreneurial Competencies.

\subsubsection{Cross-cultural competencies to entrepreneurial competencies}

Cross-cultural capabilities are needed in entrepreneurship, especially in the current conditions, where there is free market competition, resources competition, and business competition (Hasan 2007). A strategy is needed to identify international opportunities and achieve success by creating cross-cultural capabilities for business people (entrepreneurs) that will form their entrepreneurial abilities (Muzychenko 2008). Based on the above explanation, the proposed hypothesis is:

Hypothesis 3: Cross-Cultural Competencies has a significant effect on Entrepreneurial Competencies.

The relationship between variables will be described in Figure 1 as follow.

\section{Methodology}

\subsection{Sample and data collection}

This study was conducted in SMEs Fashion sector in West Java Province during 2018. The analysis unit was entrepreneurs of SMEs in the fashion sector in West Java, involving the leader, founder, or owner as the observation units. The questionnaire was an instrument to collect primary data. This study was conducted based on Micro, Small, and Medium Entrepreneurships (MSMEs) from Law number 20 of 2008. According to that Law, Small Entrepreneurship is a company whose assets are between

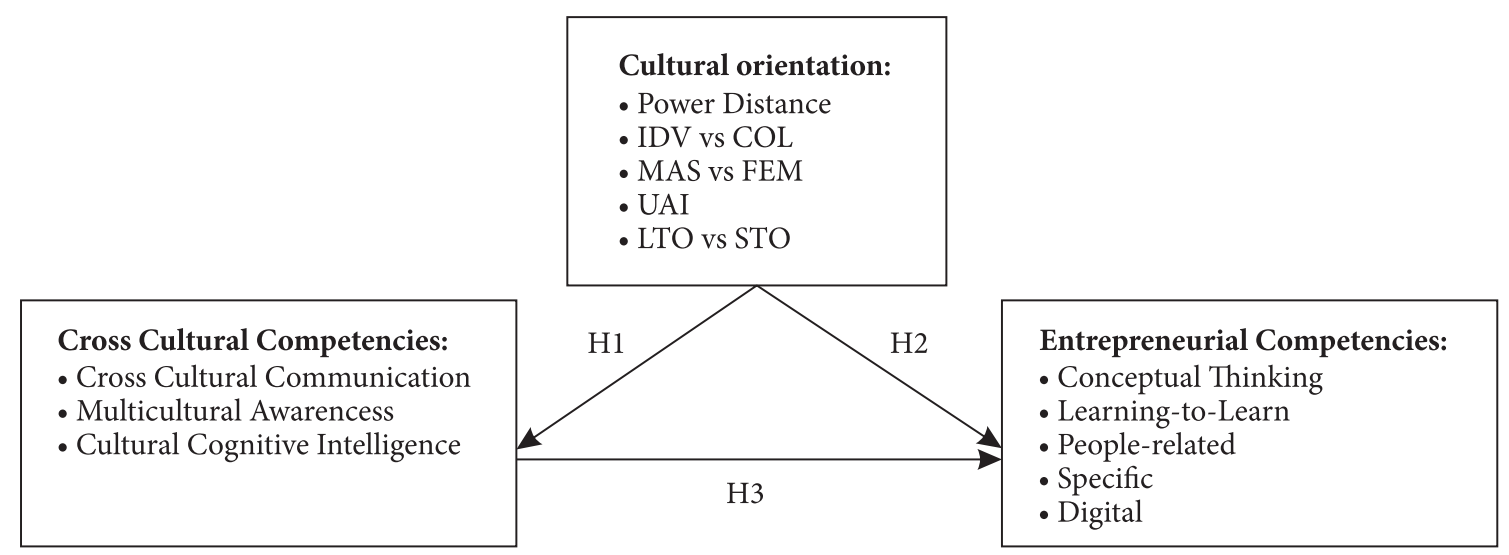

Note IDV $=$ Individualism. COLL $=$ Collectivism. MAS $=$ Masculinity. FEM $=$ Femininity. UAI $=$ Uncertainty Avoidance. LTO $=$ Long Term Orientation. STO = Short Term Orientation. vs = versus.

Figure 1. The conceptual framework 
50 million rupiahs - 500 million rupiahs and/or turnover between 300 million rupiahs -2.5 billion rupiahs, while Medium Entrepreneurship is a company whose assets are between 500 million rupiahs -10 billion rupiahs and/or turnover between 2.5 billion rupiahs -50 billion rupiahs.

According to the Ministry of Industrial and Trade of West Java Province, Indonesia, the SMEs Fashion population involved in export activities or overseas trading in this province were 181 SMEs companies. This study used Slovin's formula with a statistical significance level of 5\% (significant at $=0.05$ ) or error tolerance of $5 \%$ and a confidence level of $95 \%$. Hence, there were 125 samples minimum collected from that population and the final number sample was 129 . Since this population was homogeny, the sampling technique implemented in this study was simple random sampling.

\subsection{Measures}

Construct measurement consists of five points rating scale multiple choices lists suggested by Cooper and Schindler (2014). The instrument of this measurement consists of three parts, in which each of them is related to three main constructs namely Cultural Orientation, Cross-Cultural Competencies, and Entrepreneurial Competencies. Those measurements were adapted from the most relevant works of literature and most quoted publications. The first part of measurement tools measured five dimensions of Cultural Orientation, namely Power Distance, IDV vs. COLL, MAS vs. FEM, UAI and LTO vs. STO. This question is adopted from Hofstede (1994) and Richter et al. (2016).

The second part of measurement tools measured three dimensions of Cross-Cultural Competencies, namely Cross-Cultural Communication, Multicultural Awareness, and Cultural Cognitive Intelligence. These dimensions are adapted from Hasan (2007), Muzychenko (2008), Caligiuri and Tarique (2012), Wang et al. (2014), and Lee (2016).

Finally, the third part of measurement tools measured Conceptual Thinking, Learning to Learn, People Related, Specific, and Digital. The model of RMCS is conducted by ILO (2015), studies from Lee and Peterson (2001), Man et al. (2002), Ahmad (2007), Sajilan and Tehseen (2015), Gerli et al. (2011), Neneh and Vanzyl (2012), and SeonYoo (2015) were adopted to measure the first three dimensions, while studies from Bruin (2005) and Ünay and Zehir (2012) were adapted to create items measuring Specific, and a study from ICDL (2018) was adopted to measure Digital dimension.

\subsection{Data analysis method}

Based on data collection, descriptive and verification analyses were done. The first Descriptive Analysis was done by calculating scores and categorizing the national culture dimension used the 1994 VSM formula from Hofstede. Its reason is because it is suitable for people with a similar job or company and easier to control the number of questions (Hofstede 1994). The second Descriptive Analysis was done by developing culture archetype by evaluating the reliability and building the validity of questions in individual cultural dimension used Partial Least Square (PLS) method through exploration and confirmation factor analysis (CFA). Then, the authors checked the cultural archetypes using cluster analysis approach was developed, so similar objects would be categorized into one similar cluster (group), hence, these clusters resulting into cultural archetype. Next, these cultural archetypes were interpreted by descriptive analysis using Microsoft Excel to categorize and produce individual cultural dimensions scores.

Finally, the authors performed verification analysis to test the entrepreneur competency model hypothesis was examined with the use of national culture and individual cultural archetypes using Smart PLS to assess the author's argument empirically, with the consideration that PLS did not require multivariate normal data (Chin 1998).

\section{Results and findings}

\subsection{Respondent description}

Respondents were leaders, founders, or owners of SMEs in the fashion sector in West Java, Indonesia, who had exported and/or sold overseas (expanding internationally). Based on the questionnaire, the highest level of education was Bachelor degree (48\%), dominated by women at $73 \%$ of the total respondents. The largest age range at $41-50$ years old was $33 \%$.

\subsection{Score calculation and categorizing national culture dimension}

This study is not a comparative study against Hofstede's concepts because it is not coherent to compare the data collected from two different time terms (Lim 2001) and the sample used. However, producing scores from each dimension used the same measuring instruments and formulas as presented in the table below (Table 1).

The results and findings of this analysis were the scores and categorization of national culture dimensions by using the 1994 VSM formula from Hofstede. The scores of the VSM 1994 formula show that Indonesia represented by current fashion SMEs entrepreneurs (2019) had a small power distance (score 34.690), feminine orientation (score 30.620), low uncertainty avoidance (score 25.310), individualistic (score 76.318), and short-term orientation (score 42.636). These data and facts describe the current Indonesian National Culture and show that there has been a change in Indonesia, especially in the SMEs Industry in the Fashion sector. This change was in accordance with the suggestion of Johnson and Lenartowicz (1998) who proposed 
Table 1. The Formula of (Hofstede) 1994 VSM national culture dimensions

\begin{tabular}{|l|l|}
\hline \multicolumn{1}{|c|}{ Formula } & \multicolumn{1}{c|}{ Categories } \\
\hline PDI $=-35 \mathrm{~m}(03)+35 \mathrm{~m}(06)+25 \mathrm{~m}(14)-20 \mathrm{~m}(17)-20$ & Small - Large \\
\hline $\mathrm{IDV}=-50 \mathrm{~m}(01)+30 \mathrm{~m}(02)+20 \mathrm{~m}(04)-25 \mathrm{~m}(08)+130$ & Strongly Collectivist - Strongly Individualist \\
\hline MAS $=60 \mathrm{~m}(05)-20 \mathrm{~m}(07)+20 \mathrm{~m}(15)-70 \mathrm{~m}(20)+100$ & Strongly Feminine - Strongly Masculine \\
\hline UAI $=25 \mathrm{~m}(13)+20 \mathrm{~m}(16)-50 \mathrm{~m}(18)-15 \mathrm{~m}(19)+120 \mathrm{c}$ & Weak - Strong \\
\hline LTO $=-20 \mathrm{~m}(10)+20 \mathrm{~m}(12)+40$ & Very STO - Very LTO \\
\hline
\end{tabular}

Table 2. The validity and reliability test of individual cultural

\begin{tabular}{|l|c|c|c|c|}
\hline \multicolumn{1}{|c|}{ Dimension } & Original Sample (O) & $\begin{array}{c}\text { Standard Error } \\
(\text { STERR })\end{array}$ & $\begin{array}{c}\text { T Statistics } \\
(\mid \mathrm{O} / \text { STERR } \mid)\end{array}$ & Notes \\
\hline Individual Cultural -> COLL & 0.727 & 0.090 & 8.110 & Valid \\
\hline Individual Cultural -> LTO & 0.764 & 0.062 & 12.273 & Valid \\
\hline Individual Cultural -> MAS & 0.173 & 0.142 & 1.214 & Invalid \\
\hline Individual Cultural -> PD & -0.366 & 0.433 & 0.845 & Invalid \\
\hline Individual Cultural -> UAI & 0.762 & 0.056 & 13.715 & Valid \\
\hline
\end{tabular}

to repeat Hofstede's data, and has been conducted by several researchers such as in Malaysia by Lim (2001) and Sajilan and Tehseen (2015) and in Thailand by Rujirawanich et al. (2011). Based on the fact of changes in Indonesia that have been experiencing political reform and the globalization attack in various aspects, it was obviously necessary to repeat Hofstede's data which was carried out almost 30 years ago.

\subsection{Developing cultural archetype}

Referring to Richter et al's (2016) recommendations who expected future research to examine the predictive validity of cultural archetypes using different research contexts and non-student samples, the authors identified the possibility of new archetypes as developing Richter cultural archetypes. Thus this study also provided more statistical evidence further about the existence and impact of cultural archetypes. For this purpose, the author evaluated the cultural dimensions of Indonesian society using individual-level data. The scale used by the authors is CVSCALE suggested by Yoo et al. (2011), which was also used by Richter et al. (2016). The measurement of individual cultural dimension made it possible to calculate variability of cultural values in all individuals (Taras, Kirkman, \& Steel, 2010). For example, when $\mathrm{A}$ is born, raised, and living in the same country with $\mathrm{B}$, the A probably has different cultural value orientation with $B$ because the ethnical background is different. This will be reflected from the cultural attitude that is shown by them.

From the results of exploration and confirmation factor analysis conducted to test the validity and reliability, it was found that Power Distance (PD) and Masculinity versus Femininity (MAS) were invalid, so that the remaining three dimensions were Uncertainty Avoidance (UAI), Long Term Orientation versus Short Term Orientation (LTO), and Individualism versus Collectivism (COLL). The following is an explanation of the results of validity and reliability tests.
As performed by Richter in discovering archetype, the authors did cluster analysis using SPSS and F test. In this analysis, five Hofstede's cultural dimension had been considered on the individual level to examine whether there was a cultural archetype for respondents in Indonesia. The scores of three factors analysis results were used to create valid UAI, COLL, and LTO (Table 2) for exploration. Then, in a row, two cluster analyses were conducted (using SPSS) by applying the hierarchical grouping method followed by a centroid ( $k$-means) cluster procedure and implementing the $\mathrm{k}$-means cluster procedure to determine the best configuration of similar cultural patterns that formed a cultural base pattern (or cluster) (Richter et al. 2016). After that, F Test of cultural clusters was conducted to emphasize that the created cultural archetypes had a homogeneous cultural value structure. By checking whether the centroid cluster differs significantly from each other using ANOVA for k-means clustering, the calculation produced a significant F-value for each cluster in average. The results of the cluster analysis are as follow (Table 3-7).

Table 3. Clustering Process - 1

\begin{tabular}{|c|c|c|}
\hline \multirow{2}{*}{} & \multicolumn{2}{|c|}{ Cluster } \\
\cline { 2 - 3 } & 1 & 2 \\
\hline UAI & 16.99 & 14.97 \\
\hline COLL & 17.45 & 14.17 \\
\hline LTO & 17.65 & 15.60 \\
\hline
\end{tabular}

Table 4. Clustering Process - 2

\begin{tabular}{|c|c|c|}
\hline Cluster & 1 & 2 \\
\hline 1 & & 4.353 \\
\hline 2 & 4.353 & \\
\hline
\end{tabular}


Table 5. Clustering Process -3

\begin{tabular}{|c|c|c|c|c|}
\hline & & $\mathrm{N}$ & $\%$ of Combined & $\%$ of Total \\
\hline Cluster & 1 & 59 & $45.7 \%$ & $45.7 \%$ \\
\hline & 2 & 70 & $54.3 \%$ & $54.3 \%$ \\
\hline & Combined & 129 & $100.0 \%$ & $100.0 \%$ \\
\hline Total & & 129 & & $100.0 \%$ \\
\hline
\end{tabular}

The analysis results state that 129 respondents in this study were divided into two clusters in which the $1^{\text {st }}$ cluster was 59 respondents and 2 nd cluster was 70 respondents. The distances (4.353) between groups show that there are rather far differences between groups. Finally, the test results using ANOVA, variables with a large $F$ value and sig $<0.05$ prove that there are significant differences in those two clusters in the dimensions of UAI, COLL, and LTO.

From the grouping result of archetype cluster, those cultural archetypes were interpreted by using descriptive analysis to create scores of individual cultural dimension and categorize it afterwards according to the table below (Table 8).

In this analysis, two clusters of cultural archetypes were found for Indonesia with its characteristics that simultaneously answered questions on cultural archetype in Indonesian society. This cultural archetype was different from Indonesia's national dimension based on the calculation of VSM 1994 (Hofstede). In consonance with the opinion of Richter et al. (2016), the results of study could reveal cultural archetypes that were not in accordance with national culture and samples may not be universally valid. However, this was useful for the context of special studies and provided a basis for comparing the author's approach to perform cultural measurement with others that were commonly applied (Richter et al. 2016). Based on the score table analysis and the Individual Cultural Dimension category, the Archetype cluster 1 had 4.19 (high category) of UAI score, 3.58 (slightly high category) of COLL score, and 4.03 (high category) of LTO score. The Archetype cluster 1 can be characterized as a long-term planner in the avoidance of high uncertainty. Its members are called as Risk-Planners.

The next cluster is the Archetype cluster 2 which had 4.26 (high category) of UAI score, 3.81 (high category) of COLL score, and 4.05 (high category) of LTO score. The Archetype cluster 2 is characterized as a long-term or future orientation with strong togetherness in high uncertainty avoidance. The Archetype cluster 2 is labeled as Cooperative.

\subsection{Model testing using national culture and archetypes of individual cultural}

\subsubsection{Validity, reliability, and discriminant validity}

PLS analysis consists of two sub-models, namely measurement model and structural model. The former shows how the manifested or observed variables represented latent variables, while the latter estimates relation between variables.

The measurement model was evaluated by evaluating reliability and validity. In this case, reliability, as the consistency of measurement, helped to identify the accuracy and fidelity of items (observed variables) used to measure latent variables. For assessment, three criteria including loading factors, Cronbach's Alpha, and Composite Reliability (CR) were used. In this case, the loading of factors were first examined between the variables and their respective

Table 6. Cluster profiles

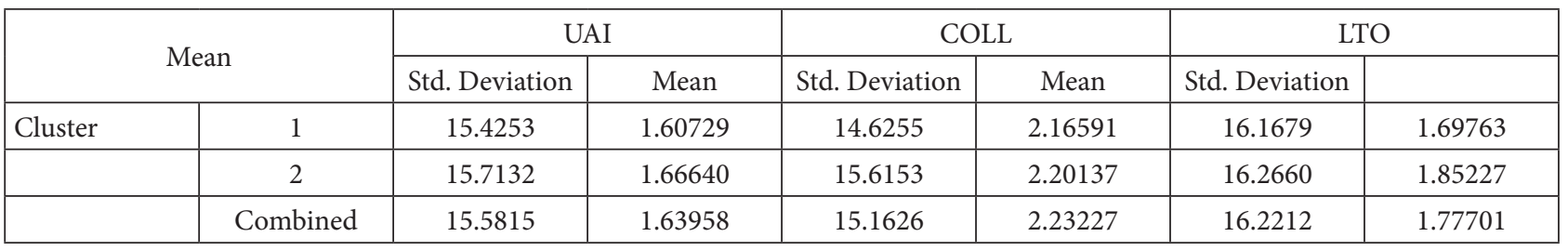

Table 7. F Test - ANOVA

\begin{tabular}{|c|c|c|c|c|c|c|}
\hline & \multicolumn{2}{|c|}{ Cluster } & \multicolumn{2}{|c|}{ Error } & \multirow{2}{*}{$\mathrm{F}$} & \multirow{2}{*}{ Sig. } \\
\hline & Mean Square & df & Mean Square & $\mathrm{df}$ & & \\
\hline UAI & 110.430 & 1 & 1.840 & 127 & 60.020 & ,000 \\
\hline COLL & 291.460 & 1 & 2.727 & 127 & 106.868 &, 000 \\
\hline LTO & 113.783 & 1 & 2.287 & 127 & 49.759 & ,000 \\
\hline
\end{tabular}

Table 8. Scores and individual cultural dimension categories

\begin{tabular}{|c|c|c|c|c|c|c|}
\hline Extremely Low & Low & Slightly Low & Moderate & Slightly High & High & Extremely High \\
\hline $1 \leq x \leq 1.5$ & $1.5<x \leq 2.2$ & $2.2<x \leq 2.7$ & $2.7<x \leq 3.3$ & $3.3<x \leq 3.8$ & $3.8<x \leq 4.5$ & $4.5<x \leq 5.0$ \\
\hline
\end{tabular}


Table 9. R-Square, validity and reliability (Cluster 1 )

\begin{tabular}{|l|c|c|c|}
\hline & $\mathrm{R}^{2}$ & $\begin{array}{c}\text { Cronbach's } \\
\text { Alpha }\end{array}$ & $\begin{array}{c}\text { Composite } \\
\text { Reliability }\end{array}$ \\
\hline $\begin{array}{l}\text { Cross-Cultural } \\
\text { Competencies }\end{array}$ & 0.316 & 0.780 & 0.840 \\
\hline $\begin{array}{l}\text { Entrepreneurial } \\
\text { Competencies }\end{array}$ & 0.554 & 0.905 & 0.872 \\
\hline Cultural Orientation & - & 0.820 & 0.862 \\
\hline
\end{tabular}

Table 10. R-Square, validity and reliability (Cluster 2 )

\begin{tabular}{|l|c|c|c|}
\hline & $\mathrm{R}^{2}$ & $\begin{array}{c}\text { Cronbach's } \\
\text { Alpha }\end{array}$ & $\begin{array}{c}\text { Composite } \\
\text { Reliability }\end{array}$ \\
\hline $\begin{array}{l}\text { Cross-Cultural } \\
\text { Competencies }\end{array}$ & 0.253 & 0.752 & 0.821 \\
\hline $\begin{array}{l}\text { Entrepreneurial } \\
\text { Competencies }\end{array}$ & 0.448 & 0.923 & 0.933 \\
\hline Cultural Orientation & - & 0.861 & 0.885 \\
\hline
\end{tabular}

indicators. According to Hulland (1999), the load must be higher than 0.4 for adequate item reliability and the load below 0.4 was issued in running the model. In addition to loading factors, internal consistency was evaluated by calculating two criteria, namely Cronbach's Alpha and Composite Reliability (CR) values. Cronbach's Alpha and CR values that aregreater than 0.7 (Fornell and Larcker 1981) implied acceptable internal consistency shown in Table 9 and 10.

Discriminant validity was measured by considering the correlation among constructs. For acceptable discriminant validity, the square root construction of their AVE must be higher than the correlation among constructs (Fornell and Larcker 1981).

The final analysis used cultural archetypes as a result of cluster analysis which produced two archetypes as separators in the context of the formation of entrepreneur competencies using the SEM-PLS model testing. This analysis was conducted to assess the authors' arguments empirically through evaluating entrepreneur competencies model by including the effects of national and individual cultural dimensions. Cluster 1 with $\mathrm{n}=59$ and cluster 2 with $\mathrm{n}=70$.

Reflective measurement model evaluation does not imply that there is a problem concerning questionnaire validity ( $\mathrm{t}$ count $>\mathrm{t}$ table $(=1.995)$ ) or $\mathrm{p}$ value $<0.05$. The internal consistency reliability is also satisfying (composite reliability $>0.7$ ). Furthermore, discriminant validity measurement shows that AVE square root is more significant compare to correlation values of latent variables. It means the instruments are following the qualifications for discriminant validity (Table 11-12).

\subsubsection{Hypotheses testing}

Although all the hypotheses of this study are acceptable as ypes, there is a difference in the amount of the contribution of influence $\left(\mathrm{R}^{2}\right)$ from the orientation role to the formation of entrepreneur competencies. In Archetype 1, the effect of cultural orientation is $31.6 \%$ of cross-cultural competencies and $55.4 \%$ of entrepreneurial competencies. This is higher than in Archetype 2 which only has $25.3 \%$ of cross-cultural

Table 11. Correlation and discriminant validity $\left(2^{\text {nd }}\right.$ order $)$ (Cluster 1$)$

\begin{tabular}{|c|l|c|c|c|c|c|c|c|c|c|c|c|}
\hline No & \multicolumn{1}{|c|}{ Dimension } & 1 & 2 & 3 & 4 & 5 & 6 & 7 & 8 & 9 & 10 & 11 \\
\hline 1 & $\begin{array}{l}\text { Conceptual } \\
\text { Thinking }\end{array}$ & 0.710 & & & & & & & & & \\
\hline 2 & $\begin{array}{l}\text { Cross-Cultural } \\
\text { Communication }\end{array}$ & 0.430 & 0.720 & & & & & & & & & \\
\hline 3 & $\begin{array}{l}\text { Cultural Cognitive } \\
\text { Intelligence }\end{array}$ & 0.307 & 0.542 & 0.776 & & & & & & & & \\
\hline 4 & Digital & 0.309 & 0.141 & 0.367 & 0.764 & & & & & & & \\
\hline 5 & IDV vs COL & 0.319 & 0.276 & 0.402 & 0.416 & 0.668 & & & & & & \\
\hline 6 & LTO vs STO & 0.419 & 0.289 & 0.457 & 0.427 & 0.404 & 0.704 & & & & & \\
\hline 7 & Learning to learn & 0.658 & 0.381 & 0.380 & 0.396 & 0.512 & 0.554 & 0.709 & & & & \\
\hline 8 & MAS vs FEM & 0.173 & 0.120 & 0.297 & 0.365 & 0.463 & 0.216 & 0.278 & 0.883 & & & \\
\hline 9 & $\begin{array}{l}\text { Multicultural } \\
\text { Awareness }\end{array}$ & 0.360 & 0.465 & 0.580 & 0.283 & 0.524 & 0.346 & 0.420 & 0.430 & 0.809 & & \\
\hline 10 & People Related & 0.524 & 0.268 & 0.484 & 0.439 & 0.562 & 0.642 & 0.587 & 0.368 & 0.461 & 0.696 & \\
\hline 11 & Specific & 0.626 & 0.390 & 0.446 & 0.412 & 0.480 & 0.367 & 0.552 & 0.285 & 0.411 & 0.562 & 0.774 \\
\hline 12 & $\begin{array}{l}\text { Uncertainty } \\
\text { Avoidance }\end{array}$ & 0.319 & 0.258 & 0.257 & 0.187 & 0.298 & 0.382 & 0.339 & 0.201 & 0.330 & 0.401 & 0.250 \\
\hline
\end{tabular}

Notes: Diagonal Bold Values are AVE square root. 
Table 12. Correlation and Discriminant Validity (2 $2^{\text {nd }}$ order) (Cluster 2$)$

\begin{tabular}{|c|c|c|c|c|c|c|c|c|c|c|c|c|c|c|}
\hline No & Dimension & 1 & 2 & 3 & 4 & 5 & 6 & 7 & 8 & 9 & 10 & 11 & 12 & 13 \\
\hline 1 & $\begin{array}{l}\text { Conceptual } \\
\text { Thinking }\end{array}$ & 0.799 & & & & & & & & & & & & \\
\hline 2 & $\begin{array}{l}\text { Cross-Cultural } \\
\text { Communication }\end{array}$ & 0.343 & 0.759 & & & & & & & & & & & \\
\hline 3 & $\begin{array}{l}\text { Cultural Cogni- } \\
\text { tive Intelligence }\end{array}$ & 0.591 & 0.343 & 0.748 & & & & & & & & & & \\
\hline 4 & Digital & 0.388 & 0.362 & 0.419 & 0.853 & & & & & & & & & \\
\hline 5 & IDV vs COL & 0.462 & 0.466 & 0.215 & 0.186 & 0.635 & & & & & & & & \\
\hline 6 & LTO vs STO & 0.546 & 0.258 & 0.534 & 0.240 & 0.414 & 0.767 & & & & & & & \\
\hline 7 & $\begin{array}{l}\text { Learning to } \\
\text { learn }\end{array}$ & 0.640 & 0.200 & 0.389 & 0.280 & 0.382 & 0.499 & 0.709 & & & & & & \\
\hline 8 & MAS vs FEM & 0.322 & 0.119 & 0.239 & 0.137 & 0.604 & 0.403 & 0.308 & 0.877 & & & & & \\
\hline 9 & $\begin{array}{l}\text { Multicultural } \\
\text { Awareness }\end{array}$ & 0.270 & 0.320 & 0.552 & 0.210 & 0.159 & 0.371 & 0.298 & 0.304 & 0.875 & & & & \\
\hline 10 & People Related & 0.707 & 0.247 & 0.396 & 0.154 & 0.446 & 0.425 & 0.592 & 0.288 & 0.209 & 0.715 & & & \\
\hline 11 & Power Distance & 0.130 & 0.127 & 0.082 & 0.019 & 0.377 & 0.390 & 0.200 & 0.325 & 0.012 & 0.137 & 0.882 & & \\
\hline 12 & Specific & 0.695 & 0.255 & 0.422 & 0.175 & 0.419 & 0.469 & 0.593 & 0.285 & 0.236 & 0.569 & 0.206 & 0.746 & \\
\hline 13 & $\begin{array}{l}\text { Uncertainty } \\
\text { Avoidance }\end{array}$ & 0.410 & 0.245 & 0.382 & 0.000 & 0.546 & 0.468 & 0.485 & 0.380 & 0.316 & 0.470 & 0.208 & 0.305 & 0.772 \\
\hline
\end{tabular}

Notes: Diagonal Bold Values are AVE square root.

Table 13. PLS structural model summary (Cluster 1)

\begin{tabular}{|c|l|c|c|c|c|c|}
\hline \multirow{2}{*}{ Hypothesis } & \multicolumn{1}{|c|}{ Structural Model } & $\begin{array}{c}\text { Original } \\
\text { Sample }(\gamma)\end{array}$ & $\begin{array}{c}\text { Standard } \\
\text { Deviation } \\
(\text { STDEV })\end{array}$ & $\begin{array}{c}\text { T Statistics }(\mid \gamma / \text { STDEV } \mid) \\
\text { P Values }\end{array}$ & Conclusion \\
\hline 1 & $\begin{array}{l}\text { Cultural Orientation -> Cross- } \\
\text { Cultural Competencies }\end{array}$ & 0.562 & 0.130 & 4.328 & 0.000 & Accepted \\
\hline 2 & $\begin{array}{l}\text { Cultural Orientation -> } \\
\text { Entrepreneurial Competencies }\end{array}$ & 0.552 & 0.104 & 5.325 & 0.000 & Accepted \\
\hline 3 & $\begin{array}{l}\text { Cross-Cultural Competencies -> } \\
\text { Entrepreneurial Competencies }\end{array}$ & 0.297 & 0.110 & 2.709 & 0.007 & Accepted \\
\hline
\end{tabular}

Table 14. PLS structural model summary (Cluster 2)

\begin{tabular}{|c|l|c|c|c|c|c|}
\hline Hypothesis & \multicolumn{1}{|c|}{ Structural Model } & $\begin{array}{c}\text { Original } \\
\text { Sample }(\gamma)\end{array}$ & $\begin{array}{c}\text { Standard } \\
\text { Deviation } \\
(\text { STDEV })\end{array}$ & $\begin{array}{c}\text { T Statistics } \\
(\mid \gamma / \text { STDEV } \mid)\end{array}$ & P Values & Conclusion \\
\hline 1 & $\begin{array}{l}\text { Cultural Orientation - Cross- } \\
\text { Cultural Competencies }\end{array}$ & 0.498 & 0.089 & 5.615 & 0.000 & Accepted \\
\hline 2 & $\begin{array}{l}\text { Cultural Orientation -> } \\
\text { Entrepreneurial Competencies }\end{array}$ & 0.474 & 0.087 & 5.454 & 0.000 & Accepted \\
\hline 3 & $\begin{array}{l}\text { Cross-Cultural Competencies }-> \\
\text { Entrepreneurial Competencies }\end{array}$ & 0.300 & 0.102 & 2.954 & 0.003 & Accepted \\
\hline
\end{tabular}


competencies and $44.8 \%$ of entrepreneurial competencies (Table 9 and 10).

Based on the categories and effects of national and individual cultural dimensions of each archetype, it is argued that argue that members in Archetype 1 do not have a power distance effect, so they are more able to express without any hierarchical limitations. Besides that, as a collectivist, COLL score is in the slightly high category, which makes members of this archetype as Risk-Planners (Risk Anticipator). The members tend to respect equality, be more independent, and focus on long-term goals in high uncertainty. Meanwhile, in Archetype 2 as a Cooperative, it is still affected by national power distance effects even though the result is small and has relatively high effect of individual cultural dimension, so achieving a goal is always based on togetherness (interdependence and reluctance). It has been noted that to make it not biased, Feminine Dimension is ignored in the characterizing process of those two archetypes because the respondents sample in the fashion sector are dominated by the female. Considering those analysis results, it is agreed that Indonesian people generally belong to the Archetype 2. It is because Indonesian people uphold values, norms, constitution, and local wisdom, such as gotong-royong (mutual cooperation), deliberation to reach consensus, silih asah silih asih silih asuh (remind each other, love each other, and guide for each other), tepo seliro (love each other), and prioritize the interests of group than personal interests. Although, for the formation of Entrepreneur Competencies, both archetypes do not reflect material success as in developed countries (Hofstede 1983) and even they are doubted to have strong competitiveness. However, Indonesian people represented by the SMEs Entrepreneurs of fashion sector in West Java still feel optimistic by this special Indonesian characteristic in facing globalization.

\section{Contribution, limitation, and future research}

\subsection{Theoretical contribution}

This study has several theoretical contributions. First, it contributes as renewal national and individual cultural values. The findings of this study contribute to the development of cultural dimension literature from Hofstede $(1980,2001)$ and Richter et al. (2016) and complement to the cross-cultural entrepreneurship literature. Second, it generates two new basic cultural patterns (archetypes), namely Risk Planner and Cooperative, which show that there is a development of concepts from Richter et al. (2016). Third, by examining the role of cultural orientation on entrepreneurial competencies, it had been found that cultural orientation positively and significantly influences the formation of entrepreneurial competencies. The results are consistent with previous research by Ahmad (2007) that cultural orientation can influence the behavior of Australian and Malaysian SMEs who describe their entrepreneurial competencies. A close connection between cultural values and individual behavior to understand how cultural values are different affects entrepreneurial behavior. Culture has a considerable impact on individuals because it is a series of values that are consistently distinctive in society (Hofstede 1991). These findings strengthen the position of cultural orientation as a predictor of competence in cross-cultural management and entrepreneurial literature. Fourth, this study found a positive and significant direct relationship between cross-cultural competencies and entrepreneurial competencies and was empirically proven. The results are consistent with previous conceptual research by Muzychenko (2008) that to identify international opportunities, a strategy is needed to create cross-cultural capabilities of entrepreneurs to shape their entrepreneurial abilities. The outcome of this study can be a reference for other studies.

\subsection{Practical contribution}

In relation to practical contributions, this study offers empirical evidence, especially for SMEs in the Indonesia's fashion industry, that there are different national culture values and new individual cultural values, which will affect entrepreneurs' ability of to manage their business. The role of Cultural Orientation, Cross-Cultural Abilities, and Entrepreneurial Competencies in this study will prepare entrepreneurs in conducting business internationally. Entrepreneurs are hoped to be able to manage risks in the global economy and compete in the globalization era (Temtime 2005, Hasan 2007, Muzychenko 2008, Groves and Feyerherm 2011). Besides that, having cross-cultural orientation and competencies will help them in international business cooperation (Cao 2012, Lee 2016). Therefore, they can become effective global leaders (Caligiuri and Tarique 2012).

\subsection{Limitations and future research}

This study obtains the novelty from renewal national culture values and individual cultural values, and the role model of Cultural Orientation on the SMEs Entrepreneur Competencies in the Fashion sector in the globalization era. However, this study still requires further investigation.

First, this study used Hofstede's concepts, gauges, and formulas $(1980,1994,2001)$, but it was not a comparative study of Hofstede's survey results. It is only one alternative view because the initial plan of this study was to obtain the latest values from national culture Hofstede for the entrepreneur competencies model. Therefore, it is hoped that there will be a future investigation for comparative research on the national culture values of Hofstede. 
Second, individual cultural values adapted from the basic cultural pattern of Richter et al. (2016) was explored as another alternative expected to be a concept development of basic cultural patterns (Richter et al. 2016). However, this study used limited sample and research sites that were only intended to test models. For this reason, future research needs to use different samples and research sites, which can create generalizations.

Third, this study was conducted a test of influence on the individual competency model. However, the competencies required in this model are still limited to the scope of human resource management science. It will certainly be more comprehensive if future research develops competencies in other management sciences in more detail.

Fourth, this study took place in SMEs in fashion sector in Indonesia. Future research is expected to be able to examine research models in different samples and research sites to obtain generalizations in this field of research.

\section{Conclusions}

According to the results of statistical data processing, the findings of this study confirmed that the proposed conceptual framework model that tested the influence of cultural orientation on entrepreneur competencies in SMEs in the globalization era was generally fit. This study has got more recent empirical evidence in identifying national and individual cultural values for Indonesia, including measuring the impact of cultural orientation on the formation of entrepreneur competencies. This is considered to expand the cultural dimension literature from Hofstede and also from other researchers such as Richter, and add the cross-cultural entrepreneurship literatures.

In line with the aforementioned description, other findings from the results of data and studies show that this study would fill the gap in the scarcity of cross-cultural competency literature in entrepreneurship; even there has not been any research that examines the direct linkages between cross-cultural competencies and entrepreneurial competencies. In addition, this study also produced new cultural archetypes and the model of the influence of Cultural Orientation on Entrepreneur Competencies in the globalization era as new findings. These findings became the novelty of this study. Thus, the role of cultural orientation and the two competencies cannot be ignored in enhancing the ability of SMEs Entrepreneurs especially for Indonesian SMEs Entrepreneurs in the fashion sector to face the current AEC era. The results and findings of this study are hoped to give valuable contribution in term of increasing human resource capacity and developing entrepreneurship in the globalization era.

\section{References}

Abbey A (2002) Cross-cultural comparison of the motivation for entrepreneurship. Journal of Business and Entrepreneurship 14 (1): 69.

Ahmad NH (2007) A cross cultural study of entrepreneurial competencies and entrepreneurial success in SMEs in Australia and Malaysia. The University of Adelaide website http://hdl.handle.net/2440/48199

Bacigalupo M et al. (2016) EntreComp: The entrepreneurship competence framework. J. S. f. P. Report, Europe Commision.

Bird B (1995) Toward a theory of entrepreneurial competency: Advances in entrepreneurship. Firm Emergence and Growth 2 (1): 51-72.

BPS-Bekraf (2016) Laporan Badan Ekonomi Kreatif Tahun 2010-2015 [Report of the Creative Economy Agency for 2010-2015] http://www.bekraf.go.id/pustaka/page/datastatistik-dan-hasil-survei-khusus-ekonomi-kreatif

Bruin A (2005) Multi-level entrepreneurship in the creative industries: New Zealand's screen production industry. International Journal of Entrepreneurship and Innovation. https://doi.org/10.5367/0000000054662791

Caligiuri P, Tarique I (2012) Dynamic cross-cultural competencies and global leadership effectiveness. Journal of World Business 47 (4): 612-622. https://doi.org/10.1016/j.jwb.2012.01.014

Cao TDQ (2012) Cultural dimensions in leadership development in joint ventures: The case of Vietnam. Doctoral dissertation, Auckland University of Technology https://core.ac.uk/download/pdf/56363151.pdf

Casero JC, Mogollón R, Roldán JL (2012) A structural model of the antecedents to entrepreneurial capacity. International Small Business Journal. https://doi.org/10.1177/0266242610385263

Chin WW (1998) The partial least squares approach to structural equation modeling. In: Marcoulides GA (Ed) Modern methods for business research. Mahwah, NJ: Lawrence Erlbaum Associates, 295-336 pp.

Cooper DR, Schindler PS (2014) Business research methods (12 ed). New York: McGraw-Hill International Edition.

Fornell C, Larcker DF (1981) Evaluating structural equation models with unobservable variables and measurement error. Journal of Marketing Research, 39-50. http://doi.org/10.2307/3151312

Gerli F, Gubitta P, Tognazzo A (2011) Entrepreneurial competencies and firm performance: An empirical study. Human Resource Management Conference Proceedings, Seville.

Groves KS, Feyerherm AE (2011) Leader cultural intelligence in context: Testing the moderating effects of team cultural diversity on leader and team performance. Group \& Organization Management 36 (5): 535-566. https://doi.org/10.1177/1059601111415664

Hasan SMJ (2007) Cross-cultural implications of entrepreneurial competencies. Eastern Washington University. https://doi.org/10.2139/ssrn.1688129

Hofstede G (1980) Culture's consequences: International differences in work-related values (integral ed.). Sage.

Hofstede G (1983) The cultural relativity of organizational practices and theories. Journal of international business studies 14 (2): 75-89. https://doi.org/10.1057/palgrave.jibs.8490867 
Hofstede G (1991) Cultures and organizations: Intercultural cooperation and its importance for survival. Software of the mind. London: Mc Graw-Hill.

Hofstede G (1994) Values Survey Module 1994 questionnaire (VSM 94). Institute for Research on Intercultural Cooperation (IRIC), Tilburg, Netherlands.

Hofstede G (2001) Culture's consequences: Comparing values, behaviors, institutions and organizations across nations. Sage publications.

Hull CEK, Hung YTC, Hair N, Perotti V, DeMartino R (2007) Taking advantage of digital opportunities: A typology of digital entrepreneurship. International Journal of Networking and Virtual Organizations 4 (3): 290-303.

https://doi.org/10.1504/IJNVO.2007.015166

Hulland J (1999) Use of Partial Least Squares (PLS) in Strategic Management Research: A review of Four Recent Studies. Strategic Management Journal 20: 195-204. https://doi. org/10.1002/(SICI)1097-0266(199902)20:2<195::AIDSMJ13>3.0.CO;2-7

Ilomäki L, Kantosalo A, Lakkala M (2011) What is digital competence? European Schoolnet http://linked.eun.org/web/ guest/in-depth3

International Computer Driving License (ICDL) Asia (2018) http://www.icdlasia.org

International Labour Organization (ILO) (2015) Regional model competency standards: Core competencies / regional skills programme. ILO Regional Office for Asia and the Pacific http://www.ilo.org/wcmsp5/groups/public/@asia/@ro-bangkok/documents/publication/wcms_420961.pdf

Johnson JP, Lenartowicz T (1998) Culture, freedom and economic growth: Do cultural values explain economic growth? Journal of World Business.

https://doi.org/10.1016/S1090-9516(99)80079-0

Johnson JP, Lenartowicz T, Apud S (2006) Cross-cultural competence in international business: Toward a definition and a model. Journal of International Business Studies 37 (4): 525-543. http://www.jstor.org/stable/3875168

Khalid S, Bhatti K (2015) Entrepreneurial competence in managing partnerships and partnership knowledge exchange: Impact on performance differences in export expansion stages. Journal of World Business 50 (3). https://doi.org/10.1016/j.jwb.2015.01.002

Lee E (2016) The cultural competency for working with Asian American clients scale: Development and validation. Research on Social Work Practice.

https://doi.org/10.1177/1049731516652730

Lee SM, Peterson SJ (2001) Culture, entrepreneurial orientation, and global competitiveness. Journal of World Business 35 (4): 401-416. https://doi.org/10.1016/S1090-9516(00)00045-6

Lim L (2001) Work-related values of Malays and Chinese Malaysians. International Journal of Cross Cultural Management 1 (2): 209-226. https://doi.org/10.1177/147059580112005

Man TWY, Lau T, Chan KF (2002) The competitiveness of small and medium enterprises A conceptualization with focus on entrepreneurial competencies. Journal of Business Venturing 17 (2): 123-142. https://doi.org/10.1016/S0883-9026(00)00058-6

Muzychenko O (2008) Cross-cultural entrepreneurial competence in identifying international business opportunities.
European Management Journal 26 (6).

https://doi.org/10.1016/j.emj.2008.09.002

Neneh NB, Vanzyl J (2012) Towards establishing long term surviving small and medium enterprises (SMEs) in South Africa: An entrepreneurial approach. African Journal of Business Management 6 (28): 8327-8343.

https://doi.org/10.5897/AJBM11.2572

Ngoasong MZ (2017) Digital entrepreneurship in a resource-scarce context: A focus on entrepreneurial digital competencies. Journal of Small Business and Enterprise Development. https://doi.org/10.1108/JSBED-01-2017-0014

Richter NF, Hauff S, Schlaegel C, Gudergan S, Ringle CM, Gunkel M (2016) Using cultural archetypes in cross-cultural management studies. Journal of International Management 22 (1): 63-83. https://doi.org/10.1016/j.intman.2015.09.001

Rujirawanich P, Addison R, Smallman C (2011) The effects of cultural factors on innovation in a Thai SME. Management Research Review 34 (12): 1264-1279. https://doi.org/10.1108/01409171111186397.

Sajilan S, Tehseen S (2015) Cultural orientations, entrepreneurial competencies and SMEs business success: The contingent roles of environmental turbulence and network competence. Review of Integrative Business and Economics Research 4 (2): 20 http://sibresearch.org/uploads/3/4/0/9/34097180/ riber_k15-003_20-35.pdf

SeonYoo (2015) A comparative study of cultural dimension as an influencing factor to entrepreneurial orientation. International Journal of Business and Social Science 6 (2): February 2015. http://ijbssnet.com/journals/Vol_6_No_2_February_2015/24.pdf

Steensma HK, Marino L, Weaver KM (2000) Attitudes toward cooperative strategies: A cross-cultural analysis of entrepreneurs. Journal of International Business Studies 31 (4): 591609. https://doi.org/10.1057/palgrave.jibs.8490924

Taras V, Kirkman BL, Steel P (2010) Examining the impact of Culture's consequences: A three-decade, multilevel, metaanalytic review of Hofstede's cultural value dimensions. https://doi.org/10.1037/a0018938

Temtime ZTPJ (2005) Managerial competency and organizational flexibility in small and medium enterprises in Botswana. Problems \& Perspectives in Management and Labor Studies (1): 25-36.

Ünay FG, Zehir C (2012) Innovation intelligence and entrepreneurship in the fashion industry. International Conference on Leadership, Technology and Innovation Management 41: 315-321. https://doi.org/10.1016/j.sbspro.2012.04.036

Van Deursen AJAM, Van Dijk JAGM (2009) Using the internet: Skill related problems in users' online behavior. Interacting with Computers. https://doi.org/10.1016/j.intcom.2009.06.005

Wang D, Feng T, Freeman S, Fan D, Zhu CJ (2014) Unpacking the "skill-cross-cultural competence" mechanisms: Empirical evidence from Chinese expatriate managers. International Business Review 23 (3): 530-541.

https://doi.org/10.1016/j.ibusrev.2013.09.001

Yoo B, Donthu N, Lenartowicz T (2011) Measuring Hofstede's five dimensions of cultural values at the individual level: Development and validation of CVSCALE. Journal of International Consumer Marketing 23 (3-4): 193-210. http://doi.org/10.1080/08961530.2011.578059 